\title{
EFFECT OF FORMALDEHYDE TREATMENT AND FEEDING REGIME OF DIETS FOR CROSSBRED FRIESIAN COWS ON MILK PRODUCTION AND MICROBIOLOGICAL STATUS
}

\author{
H.M. El-Shabrawy ${ }^{1}$ and H.A. El-Fadaly ${ }^{2}$ \\ 1- Animal Nutrition Department, Animal Production Research Institute, Agricultural \\ Research Centre, Giza, Egypt, 2- Microbiology Department, Faculty of Agriculture, \\ University of Mansoura, Mansoura, Egypt
}

\section{SUMMARY}

Sixteen lactating crossbred Friesian cows, in early lactation, were divided into 4 groups using $4 \times 4$ Latin square design throughout 30 days experimental period. Rations used consisted of berseem hay (BH) or whole corn silage (WCS) as a source of roughage and concentrate feed mixture either untreated or formaldehyde-treated. The ratio of roughage to concentrate was 40 to 60 on the basis of dry matter. Before the commencement of the experiment, the experimental rations were evaluated on sheep for their digestibility and nutritive values.

Results indicated significant $(P<0.05)$ increase in digestibility coefficients of organic matter (OM) and nitrogen-free extract (NFE) of the whole corn silage (WCS) compared to $\mathrm{BH}$ rations. The same effect was found for the nutritive value in terms of digestible energy (DE) and metabolizable energy (ME) of WCS. On the other hand, a significant effect was recorded on digestible crude protein (DCP) values for animals when received $B H$ rations compared to those received WCS. Formaldehyde treatment of concentrate feed mixture (CFM) significantly increased the CP digestibility coefficients and DCP\% as well. No significant differences were recorded for other nutrients digestibility coefficients and/or the feeding values of the tested rations.

Yield of 4\% fat corrected milk (FCM) was improved by $8.3 \%$ for cows fed on formaldehyde-treated concentrate feed mixture (F-CFM) than those fed untreated ones. Milk component yields were significantly higher in case of formaldehyde treated group than untreated corresponding. Residual formaldehyde levels in milk from cows fed F-CFM found to be negligible.

The microbiological examination included nine pathogenic bacteria namely $E$. coli, Shigella spp., Salmonella spp., Proteus spp., Yersinia spp., Brucella spp., Staphylococcus spp. and Enterococcus spp. besides fecal colifoms and total bacterial count. In addition, some mesophilic and thermophilic members of lactic acid bacteria as useful and naturally occurring microinhabitants in milk were also examined in the produced milk. The obtained milk was also used for making yoghurt to examine the effect of the residual formaldehyde on the yoghurt characters such as $\mathrm{pH}$, acidity, fats, total solids and specific gravity.

Results showed that Proteus spp. exhibited the highest decrease percentage (58.91) followed by Enterococcus spp. (52.43). E. coli and Shigella spp. exhibited decrease equal to (49.93) and (49.91), respectively. Streptococcus lactis showed the

Issued by The Egyptian Society of Animal Production 
highest decrease percentage being 14.3 followed by Streptococcus thermophilus (10.35). No significant differences between yoghurt made from treated or untreated milk when compared with the standards of the tested parameters.

Finally, it could be concluded that WCS seems to be better source of roughage than $\mathrm{BH}$ in formulating rations of lactating cows, based on better feeding values. In addition, low concentration of formaldehyde (1\%) used for treatment is strongly recommended for the protection of CFM protein to improve milk yield and its components by high yielding cows. In the meantime, formaldehyde inhibits undesirable bacteria such as pathogenic ones with low destruction percent for desirable species such as lactic acid bacteria.

Keywords: Lactating cows, diets, formaldehyde treatment, milk quality and quantity, microbiology yoghurt

\section{INTRODUCTION}

In Egypt, most farm animal breeders depend mainly on berseem hay (BH) or whole corn silage (WCS) for feeding during summer season with supplementation of concentrate feed mixture (CFM). Many sources of plant proteins are used as supplements in CFM for lactating and growing animals. Among those, undecorticated cotton seed meal, linseed meal and wheat bran, are characterized by high rumen degraded protein (Mehrez, 1981; NRC, 1989; El-Shabrawy, 1996). Two main sources of roughage such as BH and WCS are also characterized by high rumen degraded protein (Mabjeesh et al., 1997and El-Fadaly et al., 2003).

Milk yield and its protein content can be affected by the amount of CP flow into the small intestine (Hof et al., 1994). In order to magnify available protein level, undegradable protein must be added to the ration above the amount of microbial protein synthesised in the rumen (NRC, 1989). There are many methods for protein protection to increase the undegradable $\mathrm{CP}$ in rumen, e.g. $1 \%(\mathrm{w} / \mathrm{w})$ formaldehyde treatment (Ferguson et al., 1967), heat treatment (Stern et al., 1985), tannin treatment (Pace et al., 1993) and hence increasing the amount of CP escaping to the small intestine. The formaldehyde treatment method is apparently the more suitable for protection of these ingredients without severely affecting enzymatic digestion of protein (El-Shabrawy, 1996).

The main objective of this study was to investigate the effect of feeding CFM either untreated or formaldehyde-treated with different roughage sources such as $\mathrm{BH}$ or WCS on nutrients digestibility, nutritive values of the tested rations. Milk production and its components were also studied. The quality of produced milk was evaluated by making yoghurt and monitoring the microbiological status represented by pathogenic and lactic acid bacteria existence.

\section{MATERIALS AND METHODS}

This study was carried out at El-Serw Experimental Station, Animal Production Research Institute, Agricultural Research Center, Ministry of Agriculture and Land 
Reclamation, and Department of Microbiology, Faculty of Agriculture, Mansoura University, Egypt.

Animals and feed formulation

Sixteen lactating crossbred Friesian cows in early lactation were balanced for body weight, milk yield, days after calving and parity. The animals were divided into 4 groups and each received 4 rations using $4 \times 4$ Latin square design with 30 days experimental period.

The 4 experimental rations used were the following; 1) Untreated concentrate feed mixture + berseem hay $(\mathrm{U}-\mathrm{CFM}+\mathrm{BH}), 2)$ Formaldehyde treated $-\mathrm{CFM}+\mathrm{BH}$, $(\mathrm{F}-\mathrm{CFM}+\mathrm{BH}), 3) \mathrm{U}-\mathrm{CFM}+$ whole corn silage $(\mathrm{U}-\mathrm{CFM}+\mathrm{WCS})$ and 4) F-CFM + WCS.

The CFM consisted of 22\% yellow maize, $26 \%$ wheat bran, $32 \%$ undecorticated cotton seed cake, $5 \%$ linseed meal, $9 \%$ rice bran, $3 \%$ molasses, $2 \%$ limestone and $1 \%$ sodium chloride. The CFM pellets were ground (6 mm particle size) and sprayed with commercial formalin solution at the rate of $1 \mathrm{~g} \mathrm{HCHO} / 100 \mathrm{~g} \mathrm{CP}(\mathrm{w} / \mathrm{w})$ of the tested material according to Ferguson et al. (1967). All animals were fed on the tested rations formulated of $60 \%$ CFM (untreated or treated) and $40 \%$ roughage $(\mathrm{BH}$ or WCS) to satisfy their requirements, calculated according to NRC (1989).

The rations were individually weighed for animals and offered twice daily. Animals were fed individually in tie-stalls, kept in their stalls (usually $8 \mathrm{~h}$ ), then were exercised in a drylot with free access to water.

\section{Chemical analysis}

The chemical composition of ingredients and rations was carried out by the methods of AOAC (1980). The animals were machine milked twice daily. Milk samples were obtained monthly from each cow from two consecutive milking and composted proportionally for determination of fat, protein, lactose, solids-not fat (SNF) and total solids (TS) by milkoscan 133 B (AISN Foss Electric, 69 Slangeupgade DK 3400 Hillerd, Denmark). Fat corrected milk (4\% FCM) for each cow was calculated using the formula of Gaines and Overman (1938).

Formalin in the produced milk was assessed using Nash's reagent according to Naiem (1999) to measure the intensity of color developed using $412 \mathrm{~nm}$ wavelength. Quantity of formalin was calculated from the standard curve prepared by the same procedure.

\section{Digestibility trials}

Prior to commencement of the experiments, four digestion trials were conducted to evaluate the digestibility and nutritive value of the four experimental rations used to cow's feeding. Three mature Rahmani rams in average weight of $63 \mathrm{~kg}$ were involved in these trials. The rams were assigned to receive $85 \%$ of their ad lib. dry matter intake at $1600 \mathrm{~g} / \mathrm{h} / \mathrm{d}(960 \mathrm{~g}$ CFM either untreated or treated and $640 \mathrm{~g}$ roughage either $\mathrm{BH}$ or WCS). One month as a transition period was allowed between the evaluation of the two roughages. Each trial lasted for 28 days, of which the first 21 days were considered as a preliminary period and the last 7 days were the collection period. The feeds were offered twice daily at 8 a.m. and 4 p.m. Drinking water was available all time. Samples of WCS after drying at $60^{\circ} \mathrm{C}$ for 48 hours in forced air oven, berseem hay and CFM as well as feces samples were dried at $105^{\circ} \mathrm{C}$ 
for 3 hours, ground through a 1-mm screen hummer mill and analyzed for ash, crude protein $(\mathrm{CP})$, ether extract (EE) and crude fiber (CF) according to the AOAC (1980).

\section{Microbiological determination \\ Media used}

The following specific media were used, brilliant green agar for Shigella spp. at $37^{\circ} \mathrm{C}$ for $24 \mathrm{~h}$, MacConkey agar for Proteus spp. and E. coli at $37^{\circ} \mathrm{C}$ for $24 \mathrm{~h}$ (Merck, 1994). Peptone sorbitol bile agar medium was used for Yersinia spp. at $35^{\circ} \mathrm{C}$ for $48 \mathrm{~h}$ (Klausner and Donnelly, 1991). Listeria spp. was enumerated at $35^{\circ} \mathrm{C}$ for $48 \mathrm{~h}$ using tryptose phosphate agar according to Pini and Gilbert (1988). For Salmonella spp., the selenite agar medium was used at $37^{\circ} \mathrm{C}$ for $24 \mathrm{~h}$ (Collins and Lyne, 1985). Staphylococcus spp. was counted using staphylococci 110 medium at $\mathrm{pH} 7.0 \pm 0.2$ for $2 \mathrm{~h}$ at $35^{\circ} \mathrm{C}$. For Brucella spp., the Brucella agar medium was used. For total bacterial count, TGY medium was used at $35^{\circ} \mathrm{C}$ for $24 \mathrm{~h}$.

\section{Counting of pathogenic bacteria}

One $\mathrm{ml}$ of milk samples was dispersed in $9 \mathrm{ml}$ of sterile distilled water and decimal serial dilutions were prepared with vigorous shaking. From the third $\left(10^{-3}\right)$ dilutions, one-ml sample was taken and plated on different media and temperature and period of incubation varied according to the microorganisms as mentioned above. Therefore, developed colonies were counted.

\section{Counting of lactic acid bacteria}

One $\mathrm{ml}$ of the produced milk was used for making serial dilutions with vigorous shaking. From the $5^{\text {th }}$ dilution $\left(10^{-5}\right)$, one $\mathrm{ml}$ was taken and plated on the agar medium of Lee et al. (1974) at $35^{\circ} \mathrm{C}$ for the mesophilic lactic acid bacteria or at $55^{\circ} \mathrm{C}$ for thermophilic ones. Colonies were counted after incubation period of $48 \mathrm{~h}$.

\section{Statistical analysis}

The obtained data for the parameters of metabolism trails, nutritive value, milk yield and its composition were statistically analyzed by the analysis of variance using factorial design $(2 \times 2)$ in a Latin Square Design. The data of milk microbiological studies were analyzed using the completely randomized design. Duncan's Multiple Range Test was used for comparison among means at 0.05 level (Duncan, 1955). Computation was performed using SAS computer program package (SAS, 1994).

\section{RESULTS AND DISCUSSION}

\section{Chemical composition}

Results in Table (1) show that the chemical analysis of the ingredients used in this study were in normal ranges as previously reported (Maklad et al., 2000; El-Deeb, 2001). The chemical composition of the tested rations seemed similar in all nutrients, except for DM, CP and ash content which was higher in $\mathrm{BH}$ rations than those of WCS. The NFE was higher in WCS rations than those of BH rations.

\section{Digestibility coefficients and nutritive values}

Results of digestibility and feeding values are presented in Table (2). There were no significant differences among nutrients digestibility of all tested rations, except 
EE digestibility which was significantly $(\mathrm{P}<0.01)$ different. A slight increase was also observed in CP digestibility of the tested rations containing F-CFM. The feeding values expressed as TDN \%, DCP\%, DE MJ/kg DM and ME MJ/kg DM were not affected by the experimental rations. This might be related to the similar values obtained for digestibility of all used rations.

Table 1. Chemical composition of tested feed ingredients and their formulated rations (\% DM basis)

\begin{tabular}{lllllllll}
\hline $\begin{array}{l}\text { Examined } \\
\text { Items* }\end{array}$ & $\begin{array}{l}\text { DM } \\
(\%)\end{array}$ & \multicolumn{7}{c}{ Chemical composition } \\
\cline { 3 - 9 } U-CFM & 90.40 & 91.78 & 16.20 & 2.65 & 11.24 & 61.69 & 8.22 & 17.82 \\
F-CFM & 87.96 & 91.75 & 16.30 & 2.63 & 11.12 & 61.70 & 8.25 & 17.80 \\
BH & 86.92 & 91.14 & 12.17 & 2.05 & 28.33 & 48.59 & 8.86 & 16.91 \\
WCS & 28.75 & 91.92 & 8.42 & 2.24 & 25.81 & 55.45 & 8.08 & 17.58 \\
\hline \multicolumn{7}{l}{ Calculated chemical composition of the formulated experimental rations } \\
\hline U-CFM + BH & 89.01 & 89.93 & 14.59 & 2.41 & 18.07 & 54.86 & 10.07 & 17.45 \\
F-CFM + BH & 87.55 & 89.91 & 14.65 & 2.40 & 18.00 & 54.86 & 10.09 & 17.46 \\
U-CFM + WCS & 65.74 & 91.84 & 13.09 & 2.49 & 17.06 & 59.20 & 8.16 & 17.72 \\
F-CFM + WCS & 64.28 & 91.82 & 13.15 & 2.48 & 16.99 & 59.20 & 8.18 & 17.72 \\
\hline
\end{tabular}

* U-CFM: Untreated concentrate feed mixture, F-CFM: Formaldehyde treated concentrate feed mixture, BH: Berseem hay, WCS: Whole corn silage

** GE: Gross energy, calculated according to MAFF (1975) using the following equation: GE $(\mathrm{MJ} / \mathrm{kg} \mathrm{DM})=0.0226 \mathrm{CP}+0.0407 \mathrm{EE}+0.0192 \mathrm{CF}+0.0177 \mathrm{NFE}$

Table 2. Effect of roughage source and formaldehyde treatment on nutrient digestibility coefficients and nutritive values of the experimental rations

\begin{tabular}{|c|c|c|c|c|c|c|c|c|c|c|}
\hline \multirow[b]{2}{*}{$\begin{array}{c}\text { Examined } \\
\text { Items }\end{array}$} & \multicolumn{6}{|c|}{ Digestibility (\%) } & \multicolumn{4}{|c|}{ Nutritive values } \\
\hline & DM & OM & $\mathbf{C P}$ & $\mathbf{E E}$ & $\mathbf{C F}$ & NFE & $\begin{array}{l}\text { TDN } \\
(\%)\end{array}$ & $\begin{array}{c}\text { DCP } \\
(\%)\end{array}$ & $\begin{array}{c}\mathbf{D E}^{*} \\
(\mathbf{M J} / \\
\mathbf{k g} \\
\mathbf{D M}) \\
\end{array}$ & $\begin{array}{c}\mathrm{ME}^{* *} \\
(\mathrm{MJ} / \\
\mathbf{k g} \\
\mathrm{DM})\end{array}$ \\
\hline \multicolumn{11}{|c|}{ Experimental rations } \\
\hline $\mathrm{U}-\mathrm{CFM}+\mathrm{BH}$ & 57.23 & 59.10 & 63.50 & 67.39 & 43.31 & 62.30 & 57.34 & 11.70 & 10.13 & 8.31 \\
\hline $\mathrm{F}-\mathrm{CFM}+\mathrm{BH}$ & 60.88 & 63.18 & 67.09 & 81.49 & 46.80 & 66.26 & 61.70 & 12.39 & 10.83 & 8.88 \\
\hline U-CFM+WCS & 61.19 & 63.79 & 62.60 & 89.04 & 46.88 & 67.83 & 61.41 & 8.14 & 11.13 & 9.13 \\
\hline $\mathrm{F}-\mathrm{CFM}+\mathrm{WCS}$ & 63.54 & 65.94 & 64.82 & 73.90 & 50.11 & 70.34 & 62.94 & 8.47 & 11.51 & 9.44 \\
\hline \multicolumn{11}{|c|}{ Roughage source } \\
\hline $\mathrm{BH}$ & 59.05 & $61.14^{\mathrm{b}}$ & 65.29 & 74.44 & 45.05 & $64.28^{b}$ & 59.52 & $12.04^{\mathrm{a}}$ & $10.48^{b}$ & $8.59^{b}$ \\
\hline WCS & 62.37 & $64.86^{\mathrm{a}}$ & 63.71 & 81.47 & 48.49 & $69.09^{\mathrm{a}}$ & 62.17 & $8.30^{\mathrm{b}}$ & $11.32^{\mathrm{a}}$ & $9.28^{\mathrm{a}}$ \\
\hline \multicolumn{11}{|c|}{ Formaldehyde treatment } \\
\hline Untreated & 59.21 & 61.44 & $63.05^{\mathrm{b}}$ & 78.21 & 45.09 & 65.07 & 59.37 & $9.92^{b}$ & 10.63 & 8.72 \\
\hline Treated & 62.21 & 64.56 & $65.96^{\mathrm{a}}$ & 77.69 & 48.45 & 68.30 & 62.32 & $10.43^{\mathrm{a}}$ & 11.17 & 9.16 \\
\hline
\end{tabular}

Means within the same column for each effect having different superscripts are significantly different $(\mathrm{P}<0.05)$.

* $\mathrm{DE}(\mathrm{MJ} / \mathrm{Kg} \mathrm{DM})=$ Digested organic matter $\mathrm{x} 19 \quad$ (MAFF, 1975).

** ME $(\mathrm{MJ} / \mathrm{Kg} \mathrm{DM})=\mathrm{DE} \times 0.82 \quad$ (MAFF, 1975). 
These results came on line with those obtained by Krastanova et al. (1995) and Mabjeesh et al. (1997). They reported that the protection of dietary protein led to non-significant effect on nutrients digestibility with different sources of feedstuffs and protection methods.

There was no significant effect of roughage source on DM, CP, EE and CF digestibility of the tested rations. On the other hand, OM and NFE digestibilities were significantly $(\mathrm{P}<0.05)$ higher with WCS than those of $\mathrm{BH}$ rations. The higher $(\mathrm{P}<0.05)$ nutritive value in terms of $\mathrm{DE}$ and $\mathrm{ME}$ of WCS than $\mathrm{BH}$ rations could be associated by higher OM and NFE digestibilities of the former rations than the latter ones. The reverse was true for $\mathrm{DCP} \%$, since it was higher in case of $\mathrm{BH}$ containing rations. This could be explained by the increase in the favorable $\mathrm{N}$ source for rumen microbes beside the reduced dietary energy escaping ruminal degradation. These results are in harmony with the findings of El-Shabrawy et al. (2004).

Regarding the effect of protection method, the higher $(\mathrm{P}<0.05) \mathrm{CP}$ digestibility values $(65.96 \%)$ were obtained with the F-CFM ration than the untreated one $(63.05 \%)$. The protection of protein CFM enhanced DCP content of the ration from $9.92 \%$ for the untreated ration to $10.43 \%$ for the formaldehyde treated ration. The improvement in CP digestibility may be related to the formaldehyde as a protective agent of protein source. Hence reducing protein solubility and degradability in the rumen could provide more dietary protein for digestion and absorption in the small intestine, which was probably better than that of microbial proteins as reported by Atwal et al. (1995), El-Shabrawy (1996) and El-Shabrawy (2000).

\section{Milk yield}

Table (3) shows that there were no significant differences in daily milk yield and its components among the four used rations.

Although the daily milk yield and its components except fat were increased $(\mathrm{P}<$ $0.05)$ in $\mathrm{BH}$ compared with WCS rations, the numerical values were close and did not exceed 2 percentage units. This indicates that neither BH nor WCS exhibited deleterious effect.

The effects of protection using formaldehyde on milk and its components and $4 \%$ fat-corrected milk yields were significantly different where values were higher for cows fed the formaldehyde treated rations than those fed untreated ones. The increase of rumen undegradable protein (RUP) resulted in improving the yield of milk and its components, probably because of high flow of nitrogen and essential amino acids to the small intestine (Cunningham et al., 1996). These results are in agreement with those of Atwal et al. (1995). They found that the increased amount of RUP in diets of dairy cows tended to increase milk yield because of improved protein status and improved intake of metabolizable energy or both of them. 
Table 3. Effect of the experimental rations, source of roughage and formaldehyde treatment on daily milk yield and its components

\begin{tabular}{|c|c|c|c|c|c|c|c|}
\hline \multirow{2}{*}{$\begin{array}{l}\text { Examined } \\
\text { Items }\end{array}$} & \multicolumn{7}{|c|}{ Yield of milk and milk components $(\mathrm{kg} /$ head / day) } \\
\hline & Milk & $\begin{array}{c}4 \% \\
\text { FCM } \\
\end{array}$ & Fat & Protein & Lactose & SNF & TS \\
\hline \multicolumn{8}{|c|}{ Experimental rations } \\
\hline $\mathrm{U}-\mathrm{CFM}+\mathrm{BH}$ & 15.62 & 14.94 & 0.58 & 0.44 & 0.74 & 1.28 & 1.86 \\
\hline $\mathrm{F}-\mathrm{CFM}+\mathrm{BH}$ & 16.91 & 16.14 & 0.62 & 0.48 & 0.80 & 1.40 & 2.02 \\
\hline U-CFM+ WCS & 15.24 & 14.66 & 0.57 & 0.42 & 0.72 & 1.24 & 1.82 \\
\hline F-CFM + WCS & 16.56 & 15.92 & 0.62 & 0.47 & 0.79 & 1.37 & 1.99 \\
\hline$\pm \mathrm{SE}$ & 0.11 & 0.11 & 0.004 & 0.003 & 0.005 & 0.01 & 0.01 \\
\hline \multicolumn{8}{|c|}{ Roughage source } \\
\hline $\mathrm{BH}$ & $16.26^{\mathrm{a}}$ & $15.54^{\mathrm{a}}$ & 0.60 & $0.46^{\mathrm{a}}$ & $0.77^{\mathrm{a}}$ & $1.34^{\mathrm{a}}$ & $1.94^{\mathrm{a}}$ \\
\hline WCS & $15.90^{\mathrm{b}}$ & $15.29^{\mathrm{b}}$ & 0.59 & $0.44^{\mathrm{b}}$ & $0.75^{\mathrm{b}}$ & $1.30^{\mathrm{b}}$ & $1.90^{\mathrm{b}}$ \\
\hline$\pm \mathrm{SE}$ & 0.08 & 0.08 & 0.003 & 0.002 & 0.004 & 0.007 & 0.01 \\
\hline \multicolumn{8}{|c|}{ Formaldehyde treatment } \\
\hline Untreated & $15.43^{\mathrm{b}}$ & $14.80^{\mathrm{b}}$ & $0.57^{\mathrm{b}}$ & $0.43^{\mathrm{b}}$ & $0.73^{\mathrm{b}}$ & $1.26^{\mathrm{b}}$ & $1.83^{\mathrm{b}}$ \\
\hline Treated & $16.73^{\mathrm{a}}$ & $16.03^{\mathrm{a}}$ & $0.62^{\mathrm{a}}$ & $0.48^{\mathrm{a}}$ & $0.80^{\mathrm{a}}$ & $1.38^{\mathrm{a}}$ & $2.01^{\mathrm{a}}$ \\
\hline$\pm \mathrm{SE}$ & 0.08 & 0.07 & 0.003 & 0.002 & 0.004 & 0.007 & 0.01 \\
\hline
\end{tabular}

\section{Milk components}

Results presented in Table (4) indicated that the mean effect of the experimental rations on percentages of milk components was not significant. These results contradict those of Zerbini et al. (1988), who found that increased dietary RUP reduced milk fat percentage and milk fat yield. On the other hand, obtained results are in agreement with those obtained by Khorasani et al. (1996). Such discrepancy might be due to milk productivity level of cows in the different studies.

Concerning the effect of roughage source, the milk fat, lactose and SNF percentages significantly increased in WCS compared with BH rations. The increase of milk fat, lactose and SNF percentages of cows fed WCS rations may be due to better ruminal fermentation, which was observed by El-Fadaly et al. (2003). In contrast, significant $(\mathrm{P}<0.05)$ increases of milk protein and TS were obtained in milk of cows fed BH rations. The results are in agreement with those reported by Maklad et al. (2000).

In respect to the effect of protection using formaldehyde; milk protein, lactose, SNF and TS percentages significantly increased for cows fed F-CFM than those fed untreated rations (CFM). There was no significant effect of formaldehyde protection on milk fat percentage. Higher percentages of most milk components were obtained with cows fed the F-CFM ration than those of untreated one. The increase in TS in milk by protection treatment was mainly due to the form of protein and lactose in obtained milk. 
Table 4. Mean effect of the experimental rations, source of roughage and formaldehyde treatment on percentage of milk components

\begin{tabular}{|c|c|c|c|c|c|}
\hline \multirow{2}{*}{$\begin{array}{l}\text { Examined } \\
\text { Items }\end{array}$} & \multicolumn{5}{|c|}{ Milk components, $\%$} \\
\hline & Fat & Protein & Lactose & SNF & TS \\
\hline \multicolumn{6}{|c|}{ Experimental rations } \\
\hline $\mathrm{U}-\mathrm{CFM}+\mathrm{BH}$ & 3.71 & 2.81 & 4.71 & 8.20 & 11.91 \\
\hline $\mathrm{F}-\mathrm{CFM}+\mathrm{BH}$ & 3.69 & 2.85 & 4.74 & 8.27 & 11.96 \\
\hline U-CFM+ WCS & 3.75 & 2.76 & 4.73 & 8.17 & 11.92 \\
\hline $\mathrm{F}-\mathrm{CFM}+\mathrm{WCS}$ & 3.74 & 2.82 & 4.76 & 8.26 & 12.00 \\
\hline$\pm \mathrm{SE}$ & 0.007 & 0.004 & 0.01 & 0.01 & 0.001 \\
\hline \multicolumn{6}{|c|}{ Roughage source } \\
\hline $\mathrm{BH}$ & $3.70^{\mathrm{b}}$ & $2.83^{\mathrm{a}}$ & $4.72^{\mathrm{b}}$ & $8.23^{\mathrm{a}}$ & $11.93^{\mathrm{a}}$ \\
\hline WCS & $3.74^{\mathrm{a}}$ & $2.79^{\mathrm{b}}$ & $4.75^{\mathrm{a}}$ & $8.22^{\mathrm{a}}$ & $11.96^{\mathrm{b}}$ \\
\hline$\pm \mathrm{SE}$ & 0.005 & 0.003 & 0.006 & 0.009 & 0.008 \\
\hline \multicolumn{6}{|c|}{ Formaldehyde treatment } \\
\hline Untreated & 3.73 & $2.78^{\mathrm{b}}$ & $4.72^{\mathrm{b}}$ & $8.18^{\mathrm{b}}$ & $11.91^{\mathrm{b}}$ \\
\hline Treated & 3.72 & $2.83^{\mathrm{a}}$ & $4.75^{\mathrm{a}}$ & $8.26^{\mathrm{a}}$ & $11.98^{\mathrm{a}}$ \\
\hline$\pm \mathrm{SE}$ & 0.005 & 0.003 & 0.006 & 0.009 & 0.008 \\
\hline
\end{tabular}

The effect of protection using formaldehyde of plant protein sources on milk components in the literature was inconsistent (Bruckental et al., 1996; Cunningham et al., 1996). In the present study, residual formaldehyde concentration in milk from cows fed F-CFM have been found to be negligible (2.05 ppm).

Syrjala-Qvist and Setala (1982), Ismail and El-Shabrawy (2002) and El-Shabrawy et al. (2004) found that when cows were fed grass silage, CFM treated with formaldehyde, or alfalfa silage the residual formaldehyde content in milk was related to intake, being $4.00,3.11$ or $1.6 \mathrm{ppm}$, respectively. In cows fed whey treated with formaldehyde at levels of $0,13.8,27.7$ and $41.6 \mathrm{~g} /$ day, the contents of formaldehyde in their milk were 0.017, 0.034, 0.095 and $0.223 \mathrm{mg} / \mathrm{kg}$ as found by Buckley and Fisher (1984).

The concentration of formaldehyde in milk in the present study was probably safe for human nutrition. This is confirmed by Ismail and El-Shabrawy (2002), who found that Domiati cheese $(8 \%$ salt) made from milk produced by cows fed F-CFM contained very small concentrations of formalin, which was $0.650 \mathrm{ppm}$ at zero time. This concentration was decreased gradually during ripening period, which became $0.085 \mathrm{ppm}$ after 90 days, since it had no effect on obtained Domiati cheese properties.

Humans and animals exposed to endogenous formaldehyde as an essential intermediate in cellular metabolism that is required for the biosynthesis of purines, thymidine and certain amino acids (Heck et al., 1990). It is involved in methylation reactions through the tetrafolate mechanism, normal blood levels of formaldehyde in humans and animals are approximately $2.5 \mathrm{ppm}(2.5 \mathrm{mg} / \mathrm{L})$ and it is rapidly metabolized in the blood with a half-life of approximately 1.5 minutes (Clary and Sullivan, 1992).

It could be concluded that WCS is a better source of roughage than $\mathrm{BH}$ in formulating rations of lactating cows, based on better fermentation parameters in the 
rumen and improving feeding values as well. In addition, formaldehyde treatment is recommended for the protection of CFM protein at $1 \%$ to improve milk yield and its components by high yielding cows.

\section{Microbiological status of obtained milk}

Regarding the pathogenic bacteria, milk from cows either fed both untreated or formaldehyde-treated rations were examined directly after the milking process. Results recorded in Table (5) proved the presence of pathogens in milk containing $\mathrm{HCHO}$ and untreated one, but in different levels. Reduction in count as affected by $\mathrm{HCHO}$ treatment was calculated for each bacterial group and results are graphically illustrated in Fig. 1.

Table 5. Microbiological status of produced milk

\begin{tabular}{lccc}
\hline \multirow{2}{*}{$\begin{array}{l}\text { Examined pathogenic } \\
\text { bacteria }\end{array}$} & Untreated & HCHO-Treated & \pm SE \\
\hline Escherichia coli (EC) & $7.33^{\mathrm{a}}$ & $3.00^{\mathrm{b}}$ & 0.47 \\
Shigella spp. (Sh) & $5.33^{\mathrm{a}}$ & $2.67^{\mathrm{b}}$ & 0.33 \\
Proteus spp. (Pr) & $5.67^{\mathrm{a}}$ & $2.33^{\mathrm{b}}$ & 0.33 \\
Salmonella spp. (Sl) & $5.67^{\mathrm{a}}$ & $3.33^{\mathrm{b}}$ & 0.33 \\
Yersinia spp. (Ye) & 4.33 & 2.67 & 0.67 \\
Brucella spp. (Br) & 0.00 & 0.00 & 0.00 \\
Staphylococcus spp. (St) & $4.00^{\mathrm{a}}$ & $2.67^{\mathrm{b}}$ & 0.23 \\
Enterococcus spp. (En) & 6.67 & 4.67 & 0.53 \\
Fecal coliform (FC) & $7.00^{\mathrm{a}}$ & $3.33^{\mathrm{b}}$ & 0.23 \\
Total bacterial count (TC) & 184.3 & 173.3 & 9.61 \\
\hline
\end{tabular}

$* \mathrm{HCHO}=$ Formaldehyde

Means within the same row having different superscripts are significantly different $(\mathrm{P}<0.05)$.

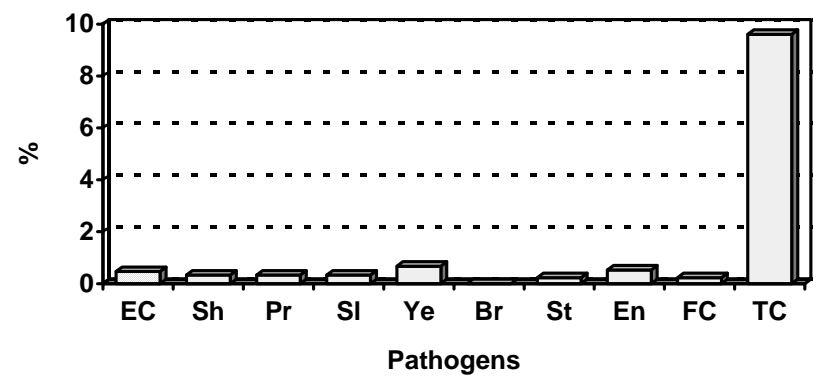

Fig. 1. Reduction percentages in numbers of some pathogenic bacteria as a result of formaldehyde treatment

Escherichia coli exhibited extraordinary reduction being $59.1 \%$ followed by Proteus spp. (58.9\%), fecal coliforms (52.4\%), then Shigella spp. and Salmonella spp. (49.9 and 41.3\%, respectively). In addition, 38.3, 33.3, 29.9 and 5.9\% decreasing 
values were found by Yersinia spp., Staphylococcus spp., Enterococcus spp. and total bacteria, respectively.

As to lactic acid bacteria as beneficial candidates naturally occurring in milk, both mesophilic and thermophilic lactic acid bacteria were tested in obtained milk containing $2.05 \mathrm{ppm}$ residual formaldehyde. Dense populations of up to $10^{7} \mathrm{cfu} \mathrm{ml}^{-1}$ for Lactobacillus plantarum and Streptococcus lactis grown at $35^{\circ} \mathrm{C}$ as well as $L$. thermophilus and $\mathrm{S}$. thermophilus grown at $55^{\circ} \mathrm{C}$ were recorded (Table 6).

Table 6. Lactic acid bacterial load of milk samples

\begin{tabular}{lccc}
\hline \multirow{2}{*}{$\begin{array}{l}\text { Examined lactic acid } \\
\text { bacteria }\end{array}$} & Untreated & $\begin{array}{l}\text { HCHO- } \\
\text { Treated }\end{array}$ & 土 SE \\
\cline { 2 - 4 } & $13.67^{\mathrm{a}}$ & $12.33^{\mathrm{b}}$ & 0.33 \\
\hline Lactobacillus plantarum (Lp) & 15.00 & 13.67 & 0.85 \\
Streptococcus lactis (S1) & $18.67^{\mathrm{a}}$ & $16.00^{\mathrm{b}}$ & 0.47 \\
Lactobacillus thermophilus (Lt) & $19.33^{\mathrm{a}}$ & $17.33^{\mathrm{b}}$ & 0.33 \\
Streptococcus thermophilus (St) & &
\end{tabular}

* $\mathrm{HCHO}=$ Formaldehyde

Means within the same row having different superscripts are significantly different $(\mathrm{P}<0.05)$.

Fig. (2) shows the reduction percentages in counts of lactic acid bacteria as affected by $\mathrm{HCHO}$ treatment. Lactobacillus plantarum (Lp) decreased by $12.2 \%$, while Streptococcus lactis (S1) recorded reduction of $14.3 \%$. In case of thermophilic lactic acid bacteria, Lactobacillus thermophilus (Lt) decreased by $8.87 \%$, while $10.35 \%$ was found for Streptococcus thermophilus (St). At 0.005\% formalin, inhibitory effect for Salmonella spp., Staph. aureus, E. coli, Bacillus spp., Streptococcus lactis, Streptococcus thermophilus and Streptococcus faecalis was observed (Mahmoud et al., 1985).

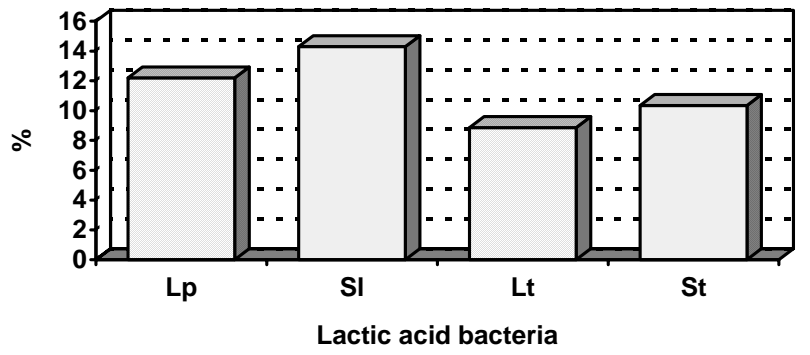

Fig. 2. Reduction percentages in lactic acid bacterial numbers due to formaldehyde treatment

Yoghurt made from obtained milk either treated with $\mathrm{HCHO}$ or untreated was evaluated and results are recorded in Table (7). The values of yoghurt $\mathrm{pH}$, acidity $(\%)$, fat (\%), total solids (\%) and specific gravity were almost similar for both yoghurt types. Comparing these parameters with standard parameters, significant correlation with $\mathrm{r}^{2}=0.999$ was obtained as seen in Fig. (3). 
Table 7. Properties of yoghurt obtained from produced milk

\begin{tabular}{lcccc}
\hline \multirow{2}{*}{ Parameters } & \multicolumn{3}{c}{ Milk used } & \multirow{2}{*}{ \pm SE } \\
\cline { 2 - 4 } & Untreated & $\begin{array}{c}\text { HCHO- } \\
\text { Treated }\end{array}$ & Standard & \\
\hline pH & 4.57 & 4.51 & 4.57 & 0.019 \\
Acidity (\%) & $0.49^{\mathrm{b}}$ & $0.51^{\mathrm{a}}$ & $0.30^{\mathrm{c}}$ & 0.003 \\
Fat (\%) & $2.47^{\mathrm{b}}$ & $2.73^{\mathrm{b}}$ & $3.30^{\mathrm{a}}$ & 0.098 \\
Total solids (\%) & $11.93^{\mathrm{b}}$ & $12.43^{\mathrm{a}}$ & $11.67^{\mathrm{b}}$ & 0.110 \\
Specific gravity & 1.04 & 1.04 & 1.04 & 0.00 \\
\hline
\end{tabular}

* $\mathrm{HCHO}=$ Formaldehyde

Means within the same row having different superscripts are significantly different $(\mathrm{P}<0.05)$.

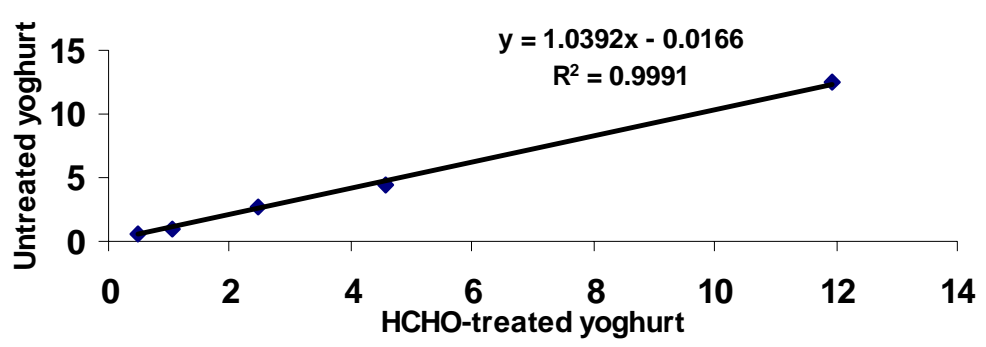

Fig. 3. Correlation between yoghurt properties obtained from formaldehyde treated and untreated milk

It is concluded that the low used concentration of formaldehyde is applicable to protect proteins from degradation in the rumen of animals and to inhibit undesirable bacteria such as pathogenic ones (Escherichia coli, Shigella spp., Proteus spp., Salmonella spp., Yersinia spp., Brucella spp., Staphylococcus spp., Enterococcus spp. and Fecal coliforms) with low destruction percent for desirable bacterial species such as lactic acid producing ones (Lactobacillus plantarum, Streptococcus lactis, Lactobacillus thermophilus and Streptococcus thermophilus).

\section{REFERENCES}

AOAC, 1980. Official Methods of Analysis. Association of Official Analytical Chemists. $13^{\text {th }}$ Ed., Washington DC, USA.

Atwal, A.S., S. Mahadevan and M.S. Wolynetz, 1995. Increased milk production of cows in early lactation fed chemically treated soybean meal. J. Dairy Sci., 78:595603.

Bruckental, I., H. Tagari, A. Arieli, S. Zamwell, Y. Aharoni and A. Genizi, 1996. The effect of undegradable crude protein supplementation on milk production and 
composition and reproduction of early-lactation cows. J. Anim. and Fd. Sci., 5:95-106.

Buckley, K.E. and L.J. Fisher, 1984. Formaldehyde residues in tissues and milk of dairy cattle consuming formalin-treated liquid whey. Res. Rev., Res. Station, Agassiz, B.C., March-Aug., 14-15.

Clary, J.J. and J.B. Sullivan, 1992. Formaldehyde. In: Hazardous Materials Toxicology. Clinical Principles of Environmental Health, Edited by Sullivan, J.B. Jr. and Krieger, G.R. Chap. 98, Williams and Wilkins, Baltimore, Hong Kong and London.

Collins, C.H. and P.M. Lyne, 1985. Microbiological Methods. The $5^{\text {th }}$ ed., Butterworths, London.

Cunningham, K.D., M.J. Cecava, T.R. Johnson and P.A. Ludden, 1996. Influence of source and amount of dietary protein on milk yield by cows in early lactation. J. Dairy Sci., 79:620-630.

Duncan, D.B., 1955. Multiple range and multiple F-test. Biometrics, 11:1-42.

El-Deeb, M.M., 2001. Evaluation of some feeds for ruminant animals. Effect of roughage: Concentrate ratio on feed utilization and some microbiological changes in the rumen of sheep. Ph.D. Thesis, Fac. Agric., Mansoura Univ., Mansoura, Egypt.

El-Fadaly, H.A., H.M. El-Shabrawy, M.M. El-Deeb and A.Z. Mehrez, 2003. Effect of formaldehyde treatment of concentrate feed mixture and source of roughage on fermentation and some bacterial activities in the rumen of sheep. The $9^{\text {th }}$ Conf. on Anim. Nutr., Hurghada, 14-17 October. Egyptian J. Nutrition and Feeds (Special Issue):1131-1142.

El-Shabrawy, H.M., 1996. Utilization of dietary protein in ruminant. Solubility and rumen degradability of some proteins and their protection. M.Sc. Thesis, Fac. Agric., Mansoura Univ., Mansoura, Egypt.

El-Shabrawy, H.M, 2000. Effect of protected proteins on the milk yield. "Influence of protecting cotton seed and soybean proteins by either heat or formaldehyde treatments on some metabolic and performance traits of Friesian cows". Ph.D. Thesis, Fac. Agric., Mansoura Univ., Mansoura, Egypt.

El-Shabrawy, H.M., A.Z. Mehrez and E.I. Shehata, 2004. Evaluation of alfalfa hay and silage in complete diets for lactating goats. The $12^{\text {th }}$ Conf. of the Egyptian Society of Animal Production, Mansoura, $30^{\text {th }}$ Nov. $2^{\text {nd }}$ Dec., Proc. of the Egyptian J. Anim. Prod., 41 (Suppl. Issue): 181-194.

Ferguson, K.A., J.A. Henslely and P.J. Reis, 1967. Nutrition on wool growth. The effect of protecting dietary protein from microbial degradation in the rumen. Aust. J. Sci., 30:215.

Gaines, W.L. and O.R. Overman, 1938. Interrelation of milk fat, milk protein and milk energy yield. J. Dairy Sci., 21:261.

Heck, H.D.A., M. Casanova and T.B. Starr, 1990. Formaldehyde toxicity-New understanding. Crit. Rev. Toxicol., 20 (6):397-426.

Hof, G., S. Tamminga and P.J. Lenaers, 1994. Efficiency of protein utilization in dairy cows. Livest. Prod. Sci., 38:169.

Ismail, M.M. and H.M. El-Shabrawy, 2002. Effect of feeding formaldehyde treated dietary on some chemical properties of Domiati cheese made from cow's milk. The $1^{\text {st }}$ Arab Mansoura Conference of Food and Dairy Sci. \& Technol., Fac. of Agric., Mansoura Univ., Egypt, October, 375-390. 
Khorasani, G.R., G. De Boer and J.J. Kennely, 1996. Response of early lactation cows to ruminaly undegradable protein in the diet. J. Dairy Sci., 79:446.

Klausner, R.B. and C.W. Donnelly, 1991. Environmental sources of Listeria and Yersinia in Vermont dairy plants. J. Food Prot., 54:607-611.

Krastanova, M., P. Lebzien and K. Rohr, 1995. The effects of protected rapeseed meal on digestion processes and amino acid supply in dairy cows. J. Anim. Physiol. \& Anim. Nutr., 73:66-76.

Lee, O.J., E.R. Vedamuthu, C.J. Washam and G.W. Reinbold, 1974. An agar medium for the differential enumeration of yoghurt starter bacteria. J. Milk Food Technol., 37:272-276.

Mabjeesh, S.J., A. Arieli, I. Bruckental, I. S. Zamwell and H. Tagari, 1997. Effect of ruminal degradability of crude protein and non-structural carbohydrates on the efficiency of bacterial crude protein synthesis and amino acid flow to the abomasums of dairy cows. J. Dairy Sci., 80:2939-2949.

MAFF, 1975. Ministry of Agriculture, Fisheries and Food. Energy Allowances and Feeding Systems for Ruminants. Technical Bull., 33, H.M.S.O., London.

Maklad, Eman, H.M. Mohamed, K. Bahira,, S.A. El-Saadany and M.A. AbdelKhabir, 2000. Comparison among the effects of clover hay and corn silages as feed ingredients on performance of lactating goats. J. Agric. Sci. Mansoura Univ., 25(2):7591-7597.

Mahmoud, S.Z., K. Naguib, S. El-Nockrashy, M.M. Sabbour and N. Tawfeek, 1985. Effect of formalin on some desirable and non-desirable organisms. Egypt. J. Dairy Sci., 13(2):159-166.

Mehrez, A.Z., 1981. Influence of basal diet and rate of passage on degradability of protein supplements in the rumen. Mansoura Univ. J. Agric. Sci., 6:106-117.

Merck, 1994. Microbiological Manual, E. Merck Darmstadt, Bereich Labor, D64271, Darmstadt, Germany.

Naiem, M.A., 1999. Evaluation of methods used for detection of formalin in milk and dairy products. Ph.D. Thesis, Fac. Agric., Mansoura Univ., Mansoura, Egypt.

National Research Council (NRC), 1989. Nutrient Requirements of Dairy Cattle. $9^{\text {th }}$ Rev. ed., Natl. Acad. Sci., Washington, DC.

Pace, V., D. Settineri and G. Cattillo, 1993. Influence of tannin treatments on the in vitro digestibility of soybean meal. Zootecnica Nut. Animale, 19:73-79.

Pini, P.N. and R.J. Gilbert, 1988. A comparison of two procedures for the isolation of Listeria monocytogenes from raw chickens and soft cheeses. Int. J. Food Microbiol., 7:331-337.

SAS, 1994. SAS User's Guide Statistics. Version 6, Fourth Ed., SAS Institute, Inc. Cary, NC., USA.

Stern, M.D., K.A. Santos and L.D. Satter, 1985. Protein degradation in rumen and amino acids absorption in small intestine of lactating dairy cattle fed heat treated whole soybeans. J. Dairy Sci., 86:45.

Syrjala-Qvist, L. and J. Setala, 1982. Formaldehyde contents of milk. II. Cows fed on grass silage preserved with formaldehyde containing additive and on formaldehyde-treated urea. J. Sci. Agric. Soc., Finland, 54(1):69-76.

Zerbini, E., C.E. Polan and J.H. Herbein, 1988. Effect of dietary soybean meal and fish meal on protein digesta flow in Holstein cows during early and mid-lactation. J. Dairy Sci., 71:1248-1258. 
تأثير معاملة العليقة بالفورمالدهيد ونظام التغذية لأبقار الفريزيان الخليط على إنتاجية اللبن ومحتواه الميكروبي

\author{
حامد محمد الثبراوى1، حسين عبد الله الفضالى 2
}

1- قسم تغنية الحيوان، معطج بحوث إنتاج الحيوان، مركز البحوث الزراعية، الجيزة، مصر. 2- قسم

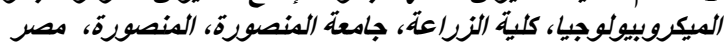

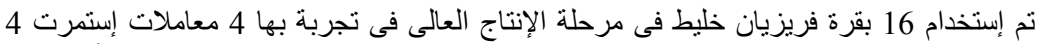

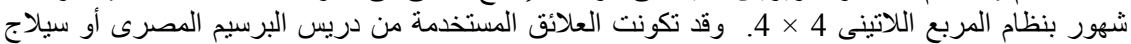

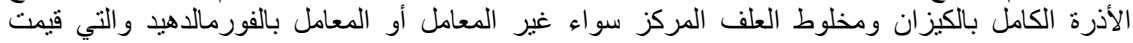

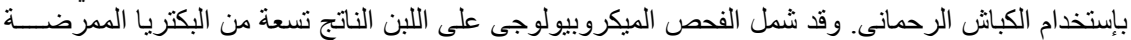

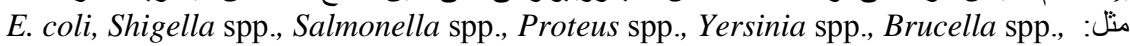
Enterococcus spp., fecal coliforms and Staphylococcus spp.

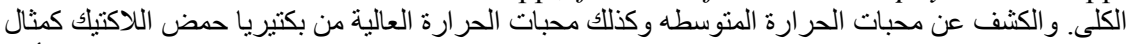

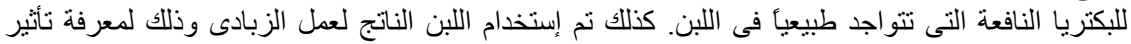

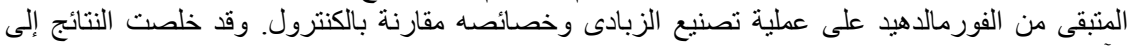

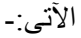

1- زيادة معاملات الهضم للمادة العضوية ومستخلص خالى الآزوت وكنللك القيمة الغذائية فى صورة الطاقة

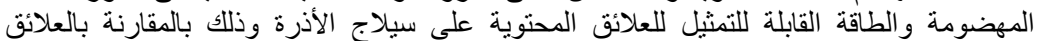

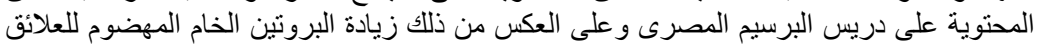

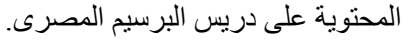

2- أدت معاملة مخلوط العلف المركز بالفورمالدهيد إلى زيادة معدلات هضم البروتين وكنلك البروتين الخام

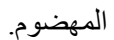

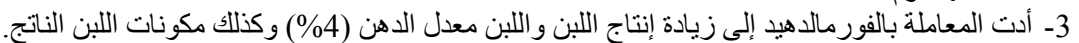

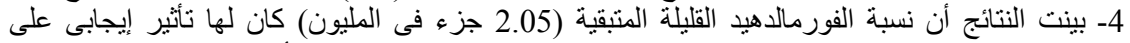

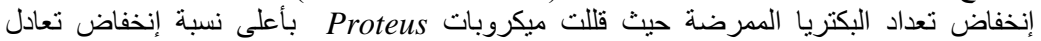

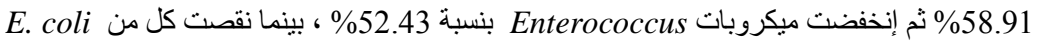
Shigella spp. ،

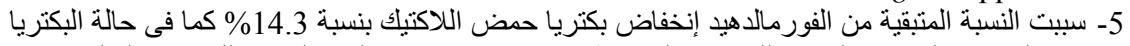

الكروية السبحية المحبة للحرارة المنوسطة ، بينما نقصت مثيلتها المحبة للحرارة العالية بنسبة النيا \%10.35

6- لم يكن هناك فروق معنوية بين صفات الزبادى المصنع من اللبن المعامل و غير المعامل آخذين في الاعتبار نسبة الحموضة ، الدهن ، الجوامد الكلية والكثافة النو عية.

أوضحت الدراسة أن سيلاج الأذرة الكامل بالكيزان كمصدر علف خشن أفضل من دريس البرسيم

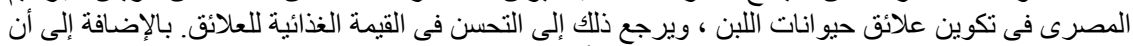

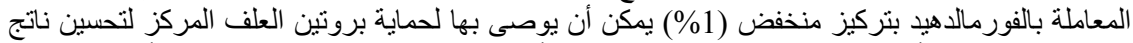

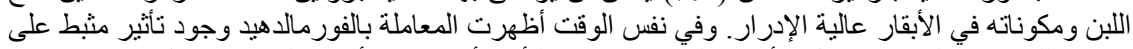

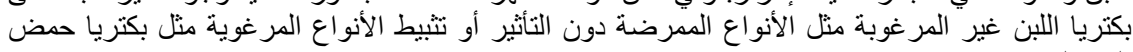

